\section{ECONOMICS}

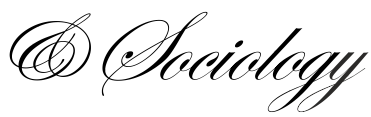

Haile, V., Szendrő, K., \& Szente, V. (2020). Students' stereotypes about instructors in higher education in Ethiopia. Economics and Sociology, 13(2), 136-149. doi:10.14254/2071-789X.2020/13-2/10

\title{
STUDENTS' STEREOTYPES ABOUT INSTRUCTORS IN HIGHER EDUCATION IN ETHIOPIA
}

\author{
Versavel Tecleab Haile \\ Institute of Marketing and \\ Management, Kaposvár University, \\ Kaposvár, Hungary \\ E-mail:Versicho@gmail.com \\ ORCID 0000-0003-3713-331X
}

\section{Katalin Szendrő \\ Institute of Marketing and \\ Management, Kaposvár University, \\ Kaposvár, Hungary \\ E-mail:szendro.katalin@,ke.bu \\ ORCID 0000-0002-0025-1059}

\section{Viktória Szente \\ Institute of Marketing and \\ Management, Kaposvár University, \\ Kaposvár, Hungary \\ E-mail:szzente.viktoria@,ke.bu \\ ORCID 0000-0001-5446-8280}

Received: August, 2019

1st Revision: March, 2020

Accepted: June, 2020

DOI: $10.14254 / 2071$ -

789X.2020/13-2/10

\author{
JEL Classification: M30, \\ M31, N37
}

\begin{abstract}
No recent study has yet examined gender stereotypes in service expectations using the SERVQUAL model in Ethiopia. Although the model has been used to measure perceived service quality and performance, customers' stereotypes in service expectations are usually overlooked. The purpose of this paper is to investigate whether students hold stereotypes and their expectations vary across the genders of their instructors. This study was conducted on three conveniently selected universities between March and April 2019. Multistage cluster sampling was used to select the students taught by both female and male instructors in the previous semester. First, the students were asked to rate their expectations of their instructors over the dimensions of service quality, namely, tangibles, reliability, responsiveness, assurance, and empathy. Consequently, no significant difference was observed across the two genders. However, when the students were asked to rate their general expectations of their instructors, they showed significantly lower expectations of female instructors than male instructors. This indicates that there is a contradiction in students' expectations which might be caused by preconception or stereotypes against female instructors. Governmental bodies, policymakers, and politicians have to be involved to take radical steps for accepting women instructors and support them in their professional works.
\end{abstract}

Keywords: expectations, service quality, gender stereotypes, Ethiopia, higher education.

\section{Introduction}

Globally, men represent a higher share of faculty members. Female faculty members are disproportionately represented in various fields of specialization. In Europe, women are a minority among senior faculty members, holding only $21 \%$ of academics in 2013 (DirectorateGeneral for Research and Innovation, 2016). Out of the full-time faculty members in Canada, women academics accounted for 40\% in 2016-2017 and women full professors accounted for 28\% of full-time teaching staff in 2017-2018 (Statistics Canada, 2017). In Australia, women 
held $45 \%$ of senior faculty positions in 2016 (Australian government, 2016). In Japan, women represented only 24\% of full-time faculty members in 2016 (Gender Equality Bureau Cabinet Office, n.d). In 2015, 32\% of full professors in the US were women (National center for education statistics, n.d). In the same year, Indian women held $25 \%$ of professor and equivalent faculty positions (All India Survey on Higher Education, n.d). In South Africa, only $25 \%$ of full professors were women in 2012 (Africa check, 2014).

In Ethiopia, the share of female faculty members is even lower. Underrepresentation of women in higher education has been unavoidable in teaching, research and leadership. Some progress has been made concerning the participation of female faculty members, yet this sector remains to be one of the areas with huge gender disparity. Only $18 \%$ of the current academic staff in Ethiopian higher education sector is female (Anouka et al., 2015).

The representation of female staff is even lower when it is further segregated by qualification and fields of studies. Only $24 \%$ of academic staff at the bachelor's level are women instructors, their share drops significantly to $12 \%$ at the master's level and goes deeper down to $8 \%$ at the $\mathrm{PhD}$ level. Women hold only $8 \%$ of positions at engineering and technology faculties of public universities; $7 \%$ in natural and computer sciences; $15 \%$ in medicine and health sciences; $11 \%$ in agricultural and life sciences; $10 \%$ in business and economics; and $11 \%$ in social sciences and humanities (The worldview, 2018).

Such underrepresentation of female faculty members has caused a lot of gender stereotypes against women. It is generally expected that women are not capable to perform and that they will not succeed at such academic posts. This stereotype of 'expected failure' implies that society doesn't trust in women's capacity to achieve. Affirmative actions also feed ideas that women are not able to achieve by themselves (Anouka et al., 2015). Gender stereotypes affect not only women but also the overall growth of Ethiopian economy. It makes a half of the current population lag behind and not perform to their full potential in social, economic and political life. This issue is very sensitive and needs urgent solutions. Given that no recent studies have been conducted to investigate students' expectations of instructors in Ethiopia, this study aims to investigate whether stereotypes exist in students' expectations of female and male instructors' performance and suggest the possible ways to bring gender equality in this area. The study adopted the SERVQUAL method to measure students' expectations and compare them in relation to female and male instructors.

The second part presents the theoretical aspects of stereotypes, expectations and the SERVQUAL model itself. The third part presents the methodology of the research while the fourth and the fifth sections present the empirical results and conclusions of the study respectively.

\section{Literature review}

\subsection{Stereotypes and expectations}

A stereotype has been defined by different authors as follows. Stereotyping is the process of ascribing characteristics to people based on their group memberships (Oakes et al., 1994). "A stereotype is an overgeneralized belief about an individual or people based on their membership in one of many social categories" (Anselmi and Law 1998, p. 195). "A stereotype is a generalization about a person or a group of people in which identical characteristics are assigned to all members of the group, regardless of actual variation among the members" (Aronson et al., 2015, p 416). A stereotype is how a person belonging to a specific group typically is or behaves (Burgess and Borgida, 1999). 
Gender stereotype results in the association of women and men to certain behavior and characteristics (Ashmore \& Del Boca, 1979). For example, characteristics such as independent, logical and effective were more attributed to males than female but women were perceived to be irrational and dependent (Bem, 1981). If women behave in any masculine way, gender prescriptive stereotypes overlap with the descriptive ones. Thus, women are expected to portray the behaviors that stereotypically match their sex but if they don't or probably show the stereotypical man characteristics, they will get negative feedback (Heilman, 2001).

The term "expectation" in service quality literature has been defined in different ways by different authors. According to Parasuraman et al. (1988), expectations can be viewed in two different ways. The expectation is depicted as the desires or wants of consumers in service quality literature. This shows what customers feel a service provider should offer rather than would offer. Whereas in satisfaction literature, expectations are viewed as predictions of customers about what is likely to happen during a service delivery process. In this study, the expectation is defined as the desires or wants of customers because the study deals with what customers expect from instructors as quality service.

In service quality literature, different researchers have investigated customers' perceptions and expectations by analyzing various dimensions of service quality. SERVQUAL is one of the most common models introduced by Parasuraman et al. (1988) designed to measure service quality. The model is composed of five dimensions namely tangibles, reliability, responsiveness, assurance, and empathy. Tangibles assess the appearance of the service setting's, physical facilities, equipment, staff appearance, and communication material. Reliability measures the ability to perform the promised service dependably and accurately. Responsiveness represents the willingness to help customers and provide prompt service. Assurance measures the knowledge and courtesy of employees and their ability to inspire trust and confidence. Empathy assesses the caring and individual attention the firm provides its customers (Parasuraman et al., 1988).

The rationale behind implementing SERVQUAL method for this study instead of other models such as (SERVPERF) by Cronin and Taylor (1994); Evaluated performance (EP) by Teas (1993); Higher Education Performance, HEdPERF model by Firdaus (2006) and the Importance performance analysis model (IPA) by Martilla and James (1977) is that all those models measure service quality based on the perception of the customers on the performance of the service provider only, however, this study aims to investigate the expectation of students.

\subsection{Stereotypes, personality traits, and gender roles}

Gender-based stereotypes of students towards the instructor could be either favouring a male or female instructors. When students form expectations of educational service, they could base their expectations on the gender of the instructor. What they expect from male instructors could be different from what they would expect from female instructors. Such differences in student's expectations could stem from the personality and role difference between males and females.

Stereotypes and prejudice at work are too often the results of such gender stereotypes in the public and the grouping of personality as masculine or feminine. Moreover, Eagly (2003) suggest that characteristics such as assertive, ambitious, aggressive, independent, selfconfident, daring and competitive are usually recognized in men, whereas communal characteristics such as a concern for other people and being affectionate, helpful, kind, sympathetic, interpersonally sensitive, nurturing, and gentle are identified in women. These interesting findings explain the fact that student's expectations of service may be shaped and constructed by the gender-based characteristics played by male and female instructors. 
There are certain types of characteristics that students would expect to see from their female and male instructors that are associated with the instructor's gender. As a result, when instructors violate the gender expectation they will be rated less (Chamberlin and Hickey, 2001; Dalmia et al., 2005; Sprague and Massoni, 2005).

Gender expectations in the workplace are highly constructed by gender roles (Risman, 2004). Men are expected to have competence, credibility and are considered as professors who have authority, while women are assumed to be less capable and less competent and are considered as instructors with less power (Johnson, 2003; Miller and Chamberlin, 2000; Morris, 2011). Women and men have certain roles in society that affect individual beliefs and gender attitudes. The belief about what men and women are capable of doing/not doing and how women and men are expected to behave can be influenced by traditional gender roles that are established in the human mind at an early age (Koenig, 2018).

Ethiopia is one of the countries where gender equality is a vision but not yet a reality. It is a patriarchal country with a strong religious and cultural foundation that affects the way people perceive women. Women in Ethiopia are regarded as unproductive parts of society and hold lower position than men. They have been disadvantaged in several ways such as low status in their society, livelihoods, basic human rights, literacy, health, and employment (UN women, n.d). According to the Global Gender Gap report (2010), Ethiopia is ranked 121 out of 134 countries in terms of gender disparities. With such minimal gender balance, women in Ethiopia are discriminated for cultural and religious excuses. Thus, students' gender expectations of the instructor in Ethiopian higher education could be influenced by gender role complexities.

\section{Methodological approach}

This study is a cross-sectional study that was conducted between March and April 2019 in Addis Ababa, Ethiopia. Data were collected from secondary sources (scientific studies and literature) and primary sources (survey). This study used 22 pairs of items designed to assess the five dimensions of service quality in the SERVQUAL model (Parasuraman et al., 1988).

Students were asked to tell their expectations of service performance on a five-point scale with end anchors "strongly agree" and "strongly disagree". Then the expectations scores were compared between female and male instructors. To investigate if students hold a stereotype, a set of supportive questions to the existing model were asked to tell students' expectation of service from female and male instructors and their preferences of the gender of the instructor. Chi-square test was used to analyse if there exists a significant relationship between the instructors' gender and students' expectation. The survey was conducted on 450 students ( $2^{\text {nd }}$ and $3^{\text {rd }}$ year) enrolled in three Addis Ababa University campuses.

Addis Ababa University has 15 campuses of which 3 are located out of the city. The survey was conducted on 3 campuses. Out of each campus, 3 departments were chosen. Two types of sampling technique are employed throughout the data collection procedure. The selection of the universities and class years were done based on convenient sampling. Once the universities were selected, multi-stage cluster sampling was made based on the departments. Then the sample was reduced to a smaller cluster based on classes taught by female instructors. In Addis Ababa University there are departments with only male instructors, therefore, it was necessary to select departments where female instructors also teach. Departments were selected based on the class where female instructors taught in the last semester.

College of Business and Economics, School of Commerce has 6 departments in it out of which 4 departments had a female teacher taught in the past semester and 3 departments were selected for the study. Accordingly, accounting, marketing, and management departments were chosen. The departments have a total of 301 students. Out of that 209 students were taught by both female and male instructor in the past semester and 150 students were reached. 
College of Natural and Computational Sciences has 7 departments out of which 4 departments had a female instructors taught in the past semester and 3 departments were selected. These are biology, mathematics, and computer science and altogether have 397 students of which 243 were taught by female instructors and 150 were reached. Whereas social work, print and web, and public relation departments were selected from the College of Social Sciences and College of Humanities, Language Studies, Journalism and Communication. The departments have a total of 400 students of which 200 were taught by female instructors and 150 were reached. Hence 450 samples were taken on the three campuses.

The 3 campuses were selected on the ground that first, they have the best composition of study of fields where both female and male students are enrolled in and the institutes in the campus are conducive for the study because they have a more likely proportionate number of women and men instructors which makes the study unbiased. Second, they have the biggest number of colleges compared to the other campuses. Third, the campus accommodates a larger number of students than the rest of the other campuses. Not to mention that the campuses consist of the largest share of students coming from different parts of Ethiopia with diversified cultures and backgrounds. This contributes to the generalization of the study result.

To distribute the questionnaire, first, class schedules of the last semester were collected from the departments, then classes taught by female instructors were screened, finally, those classes were reached out for the survey. The questionnaires were distributed to all students while they were in the class. First-year students were excluded from the survey because we believe that sophomores and meddlers know better about the education service than the juniors. 500 questionnaires were distributed to students but only 450 were valid for analysis. Consent for collecting the data was first asked from the designated instructors and there was no time limit to fill the questionnaires. Every student had an equal chance of filling the survey and it took approximately 15-20 minutes. As it can be seen in Table 1 the sample covered 9 departments and both female and male students.

Data analysis was carried out using SPSS 24. The results of the reliability analysis showed that coefficients of alpha for all the dimensions is above 0.85 And, Kaiser-Meyer-Olkin Measure of sampling Adequacy indicted an index of 0.89. Factor analysis and chi-square test were carried out to analyse the data.

Table 1. Students' demographic information

\begin{tabular}{llcc}
\hline \multirow{2}{*}{ Sex } & & Frequency & $\%$ \\
\hline \multirow{2}{*}{ Department } & Male & 209 & 46.0 \\
& Female & 241 & 54.0 \\
\cline { 2 - 4 } & Accounting & 54 & 12.0 \\
\cline { 2 - 4 } & Biology & 56 & 12.0 \\
\cline { 2 - 4 } & Computer science & 61 & 14.0 \\
\cline { 2 - 4 } & Management & 42 & 9.0 \\
\cline { 2 - 4 } & Marketing & 54 & 7.0 \\
\cline { 2 - 4 } & Mathematics & 31 & 9.0 \\
\cline { 2 - 4 } & Print and web & 40 & 10.0 \\
\cline { 2 - 4 } & Public relation & 45 & 15.0 \\
\cline { 2 - 4 } & Social work & 67 & 100.0 \\
\cline { 2 - 4 } & Total & 450 & 47.0 \\
\hline \multirow{2}{*}{ Year } & Second year & 211 & 53.0 \\
\hline
\end{tabular}

Source: own compilation 


\section{Results and discussion}

\subsection{Students expectation scores}

The expectations score were compared between female and male instructors. However, no significant difference was seen between the two genders. This implies that students' expectation does not vary across the gender of the instructor over the five dimensions of service quality. As indicated in Table 2, a higher expectation score was observed on "assurance" while "empathy" accounted for the lowest expectation score.

Table 2. Expectations scores

\begin{tabular}{|c|c|c|c|c|}
\hline \multirow[t]{2}{*}{ Statements } & \multicolumn{2}{|c|}{ Female instructors } & \multicolumn{2}{|c|}{ Male instructors } \\
\hline & $\begin{array}{c}\text { Mean } \\
(\mathrm{E})\end{array}$ & SD & $\begin{array}{c}\text { Mean } \\
(\mathrm{E})\end{array}$ & $\mathrm{SD}$ \\
\hline \multicolumn{5}{|l|}{ Tangibles } \\
\hline The instructor's reparation of up to date handouts & 4.26 & 0.90 & 4.22 & 0.93 \\
\hline The instructor's use of visually appealing physical facilities & 3.87 & 1.00 & 4.12 & 0.84 \\
\hline The instructor's use of visually appealing teaching materials & 4.08 & 0.85 & 4.17 & 0.99 \\
\hline The instructor's professional apperance & 4.16 & 0.90 & 4.17 & 0.90 \\
\hline Total & 16.37 & & 16.68 & \\
\hline \multicolumn{5}{|l|}{ Reliability } \\
\hline $\begin{array}{l}\text { The instructor's interest in solving your problem related to the } \\
\text { class }\end{array}$ & 4.11 & 1.00 & 3.94 & 1.05 \\
\hline $\begin{array}{l}\text { The instructor's interest in solving your general problems } \\
\text { outside the class }\end{array}$ & 3.49 & 1.36 & 3.60 & 1.21 \\
\hline The instructor's willingness to provide services as promised & 4.03 & 1.02 & 3.97 & 1.06 \\
\hline The instructor's ability to get things right the first time & 3.95 & 0.90 & 3.91 & 1.00 \\
\hline The instructor's ability to maintain error free records and grades & 4.11 & 1.04 & 3.91 & 1.10 \\
\hline Total & 19.69 & & 19.33 & \\
\hline \multicolumn{5}{|l|}{ Responsiveness } \\
\hline $\begin{array}{l}\text { The instructor's accuracy of informing you when class and } \\
\text { exams will be carried }\end{array}$ & 4.18 & 1.00 & 4.30 & 0.81 \\
\hline The instructor's dedication to finish the course on time & 4.33 & 0.80 & 4.19 & 0.91 \\
\hline The instructor's attention to respond to your requests & 4.04 & 0.90 & 3.91 & 0.95 \\
\hline $\begin{array}{l}\text { The instructor's honesty in giving fair grade and non } \\
\text { discriminating }\end{array}$ & 4.18 & 1.10 & 4.32 & 0.91 \\
\hline Total & 16.73 & & 16.72 & \\
\hline \multicolumn{5}{|l|}{ Assurance } \\
\hline The comfort you feel in approaching the instructor & 3.96 & 1.07 & 3.96 & 0.99 \\
\hline The instructor's ability to build confidence in your performance & 3.80 & 1.17 & 3.86 & 1.04 \\
\hline The instructor's politeness to you & 3.93 & 1.00 & 3.96 & 0.98 \\
\hline The instructor's encouragement of student expression & 4.13 & 0.91 & 4.04 & 0.88 \\
\hline The instructor's knowledge to teach the subject & 4.40 & 0.84 & 4.20 & 0.96 \\
\hline Total & 20.22 & & 20.02 & \\
\hline \multicolumn{5}{|l|}{ Empathy } \\
\hline The convenience of the instructor's office hours & 4.08 & 0.99 & 4.08 & 0.91 \\
\hline The individual attention you receive from your instructor & 3.77 & 1.00 & 3.77 & 1.01 \\
\hline The instructor's having your best interests at heart & 3.64 & 1.08 & 3.82 & 1.02 \\
\hline The ability of the instructor to understand your specific need & 3.75 & 1.21 & 3.78 & 1.00 \\
\hline Total & 15.75 & & 15.45 & \\
\hline
\end{tabular}

Source: own compilation. Note: "E" represents expectation 


\section{Factor analysis}

The total data fit into 5 components and all variables above 0.40 were maintained. The decision to include a variable in a factor was based on factor loadings greater than \pm 0.3 (Hair et al., 1995).The extracted components of the data explained nearly $61 \%$ of the variability in the original 22 variables. The rotated component matrix as shown in Table 3 indicated a very arbitrary grouping of the variables. Many of the items loaded on several components making the variable loading difficult to interpret. Thus, the result did not support the five-dimension SERVQUAL model proposed by Parasuraman et al. (1988).

Table 3. Rotated component matrix for female and male instructors

\begin{tabular}{|c|c|c|c|c|c|}
\hline \multirow[t]{2}{*}{ Statements } & \multicolumn{5}{|c|}{ Component } \\
\hline & 1 & 2 & 3 & 4 & 5 \\
\hline $\begin{array}{l}\text { Your expectation about the ability of the instructor to understand } \\
\text { your specific need }\end{array}$ & .840 & & & & \\
\hline Your expectation about the instructor's having your best interests & .771 & & & & \\
\hline $\begin{array}{l}\text { Your expectation about the individual attention you receive from } \\
\text { your instructor }\end{array}$ & .761 & & & & \\
\hline $\begin{array}{l}\text { Your expectation about the instructor's ability to build confidence } \\
\text { in your class performance }\end{array}$ & .560 & & & & \\
\hline $\begin{array}{l}\text { Your expectation about the convenience of the instructor's office } \\
\text { hours }\end{array}$ & .519 & & & & \\
\hline Your expectation about the instructor's politeness to you & .518 & & & & \\
\hline $\begin{array}{l}\text { Your expectation about the comfort you feel in approaching the } \\
\text { instructor with concerns }\end{array}$ & .451 & & & & \\
\hline $\begin{array}{l}\text { Your expectation about the instructor's knowledge to teach the } \\
\text { subject }\end{array}$ & & .775 & & & \\
\hline $\begin{array}{l}\text { Your expectation about the instructor's encouragement of student } \\
\text { expression }\end{array}$ & & .731 & & & \\
\hline $\begin{array}{l}\text { Your expectation about the instructor's dedication to finish the } \\
\text { course on time }\end{array}$ & & .524 & & & \\
\hline $\begin{array}{l}\text { Your expectation about the instructors honesty in giving fair } \\
\text { grade and not discriminating students }\end{array}$ & & .493 & & & \\
\hline $\begin{array}{l}\text { Your expectation about the Instructor's attention to respond to } \\
\text { your requests all the time you needed }\end{array}$ & & .440 & & & \\
\hline $\begin{array}{l}\text { Your expectation about the instructor's provision of well- } \\
\text { organized and informative handouts }\end{array}$ & & & .817 & & \\
\hline $\begin{array}{l}\text { Your expectation about-the instructor's preparation of up to date } \\
\text { handouts }\end{array}$ & & & .764 & & \\
\hline $\begin{array}{l}\text { Your expectation about the instructor's professional appearance } \\
\text { and dressing }\end{array}$ & & & .520 & & \\
\hline $\begin{array}{l}\text { Your expectation about the instructor's willingness to provide } \\
\text { services at time promised to do so }\end{array}$ & & & .506 & & \\
\hline $\begin{array}{l}\text { Your expectation about the accuracy of the instructor to } \\
\text { maintaining error free records and grades }\end{array}$ & & & & .683 & \\
\hline $\begin{array}{l}\text { Your expectation about the instructor's ability to get things right } \\
\text { the first time not causing rework }\end{array}$ & & & & .617 & \\
\hline $\begin{array}{l}\text { Your expectation about the instructor's interest in solving your } \\
\text { general problems outside the class }\end{array}$ & & & & .613 & \\
\hline $\begin{array}{l}\text { Your expectation about the instructor's interest in solving your } \\
\text { problem related to the class }\end{array}$ & & & & .497 & \\
\hline $\begin{array}{l}\text { Your expectation about the instructor's use of visually attractive } \\
\text { teaching materials }\end{array}$ & & & & .418 & \\
\hline $\begin{array}{l}\text { Your expectation about the Instructor's accuracy in telling you } \\
\text { exactly when class and exams will be carried }\end{array}$ & & & & & .780 \\
\hline
\end{tabular}

Source: own compilation 


\subsection{Students stereotypes}

Chi-Square test was used to analyze if there exists a significant relationship between the instructor's gender and student's expectations, and a significant relationship was indicated ( $\mathrm{p}<$ 0.05). The detail of the whole analysis is as follows.

\subsubsection{Students' expectation of the instructors' gender}

When a majority of students think of an instructor "a male figure" pops up in their mind. Many of the students $(62 \%)$ think that instructors are males. Students who think instructor as female and both genders are $11 \%$ and $24 \%$, respectively, whereas the rest $3 \%$ are indifferent (Table 4).

Table 4. Students' expectation of the instructors' gender

\begin{tabular}{|c|c|c|c|c|c|c|c|c|c|}
\hline \multirow{3}{*}{\multicolumn{2}{|c|}{$\begin{array}{l}\text { Expectation of service } \\
\text { quality }\end{array}$}} & \multicolumn{6}{|c|}{ Gender of the instructor } & \multirow{4}{*}{$\begin{array}{c}\text { Chi-Square } \\
\text { Value }\end{array}$} & \multirow{2}{*}{$\mathrm{P}$-value } \\
\hline & & \multicolumn{2}{|c|}{ Female } & \multicolumn{2}{|c|}{ Male } & \multicolumn{2}{|c|}{ Total } & & \\
\hline & & $\mathrm{N}$ & $\%$ & $\mathrm{~N}$ & $\%$ & $\mathrm{~N}$ & $\%$ & & \\
\hline \multirow{4}{*}{$\begin{array}{l}\text { Which gender } \\
\text { pops up in your } \\
\text { mind first when } \\
\text { you think of an } \\
\text { instructor? }\end{array}$} & Male & 132 & 60.0 & 141 & 64.0 & 273 & 62.0 & & \multirow{4}{*}{$0.004 * *$} \\
\hline & Female & 35 & 16.0 & 12 & 6.0 & 47 & 11.0 & \multirow{3}{*}{13.14} & \\
\hline & None & 8 & 4.0 & 6 & 3.0 & 14 & 3.0 & & \\
\hline & Both & 48 & 22.0 & 60 & 27.0 & 108 & 24.0 & & \\
\hline
\end{tabular}

Source: own compilation. $* *$ indicates significance level at 0.05

The finding shows a significant relationship between the instructors' gender and students' expectation about instructors' gender $(\mathrm{P}=0.001)$. Students' gender didn't matter in attributing instructors as male. Regardless of their gender, most of the students had the thought of men when they think of instructors. Female students accounted 54\% compared to $46 \%$ of male students. This shows that the conceptualization of male as an instructor than a female is not associated with the gender of the students. It is rather a widely spread idea and accepted by the general population.

The gender-based stereotype of students could be because of the low female literacy rate in Ethiopia. According to the World Bank (n.d), Ethiopian female literacy of aged 15-24 was $47 \%$ compared to $63 \%$ of males the same age. Educational attainment of the female population who aged 25 and above who completed a bachelor's degree or equivalent was $0.4 \%$ while the male population of the same age accounted for $2.0 \%$. Because of the educational gender gap, a male is more regarded as an instructor than a female. Globally, women are often assumed to have less academic rank than men (Carson, 2001). Miller and Chamberlin (2000) revealed gender disparities in the attribution students give to female and male faculty members. Despite the position held by male and female faculty members, students attributed the Ph.D. achievement to a man, even to the male graduate instructor. Whereas, students were less likely to attribute a Ph.D. to the woman even to a full professor. The authors believe that such misattribution of students is associated with the imputed statuses "teacher for women", and "professor for men". Female instructors have reported that students call them "Ms." rather than "Dr" while their male colleagues become "Prof." rather than "Mr" even when it is their proper title (Carson, 2001). 


\subsubsection{Students' expectation of service quality from female and male instructors}

The service quality that students expect from female instructor is significantly lower than what they would expect from a male instructor. Only $27 \%$ of students expect a very good service from female instructors compared to $59 \%$ of the male instructors (Table 5 and 6). The relationship between the instructors' gender and students' expectation of service quality is significant $(\mathrm{P}<0.001)$ such that women instructors are rated lower than men instructors. There was no significant difference between male and female students in rating female instructors. However, female students rated male instructors higher than male students $(\mathrm{P}=0.007)$ showing a significant difference between the genders.

Different researches have also come up with similar findings. Boring (2017) and MacNell et al. (2015) argued that students give lower scores to women than men for the same level of teaching effectiveness. Arbuckle and Williams (2003) also found that students hold a strong gender stereotype against women favoring male faculty members.

Table 5. Students' expectation of service quality from female instructors

\begin{tabular}{|c|c|c|c|c|c|c|c|c|c|}
\hline \multirow{3}{*}{\multicolumn{2}{|c|}{$\begin{array}{l}\text { Expectation of service } \\
\text { quality }\end{array}$}} & \multicolumn{6}{|c|}{ Gender of the instructor } & \multirow{3}{*}{ Chi-Square } & \multirow{3}{*}{ P-value } \\
\hline & & \multicolumn{2}{|c|}{ Female } & \multicolumn{2}{|c|}{ Male } & \multicolumn{2}{|c|}{ Total } & & \\
\hline & & $\mathrm{N}$ & $\%$ & $\mathrm{~N}$ & $\%$ & $\mathrm{~N}$ & $\%$ & & \\
\hline \multirow{5}{*}{$\begin{array}{l}\text { What kind of } \\
\text { service do you } \\
\text { expect from } \\
\text { female } \\
\text { instructors? }\end{array}$} & $\begin{array}{l}\text { Very } \\
\text { good }\end{array}$ & 46 & 21 & 73 & 33 & 119 & 27 & \multirow{5}{*}{33.87} & \multirow{5}{*}{$<0.001 * *$} \\
\hline & Good & 74 & 33 & 87 & 40 & 161 & 36 & & \\
\hline & Average & 41 & 19 & 46 & 21 & 87 & 20 & & \\
\hline & Poor & 34 & 15 & 8 & 3 & 42 & 9 & & \\
\hline & $\begin{array}{l}\text { Very } \\
\text { poor }\end{array}$ & 27 & 12 & 8 & 3 & 35 & 8 & & \\
\hline
\end{tabular}

Source: own compilation. $* *$ indicates significance level at 0.05

Table 6. Students' expectation of service quality from male instructors

\begin{tabular}{|c|c|c|c|c|c|c|c|c|c|}
\hline \multirow{3}{*}{\multicolumn{2}{|c|}{$\begin{array}{l}\text { Expectation of service } \\
\text { quality }\end{array}$}} & \multicolumn{6}{|c|}{ Gender of the instructor } & \multirow{3}{*}{ Chi-Square } & \multirow{3}{*}{ P-value } \\
\hline & & \multicolumn{2}{|c|}{ Female } & \multicolumn{2}{|c|}{ Male } & \multicolumn{2}{|c|}{ Total } & & \\
\hline & & $\mathrm{N}$ & $\%$ & $\mathrm{~N}$ & $\%$ & $\mathrm{~N}$ & $\%$ & & \\
\hline \multirow{5}{*}{$\begin{array}{l}\text { What kind of } \\
\text { service do you } \\
\text { expect from } \\
\text { male } \\
\text { instructors? }\end{array}$} & $\begin{array}{l}\text { Very } \\
\text { good }\end{array}$ & 106 & 48 & 154 & 69 & 260 & 59 & \multirow{5}{*}{24.79} & \multirow{5}{*}{$<0.001 * *$} \\
\hline & Good & 79 & 36 & 53 & 24 & 132 & 30 & & \\
\hline & Average & 30 & 13 & 11 & 5.0 & 41 & 9 & & \\
\hline & Poor & 6 & 3.0 & 3 & 1.4 & 9 & 2 & & \\
\hline & $\begin{array}{l}\text { Very } \\
\text { poor }\end{array}$ & 0 & 0.0 & 1 & 0.6 & 1 & 0 & & \\
\hline
\end{tabular}

Source: own compilation. ** indicates significance level at 0.05

Further, the experimental study of Goldberg (1968) revealed that college students showed gender bias, attributing more positive evaluations to a male-authored article even when the journal article varied only in terms of its author's sex. In a similar experiment, Noel and Allen (1976) asked students to rate the quality of writing in essays. The study found that both male and female students rated the essays as being lower quality if they believed the author was female. 


\subsubsection{Students' preference for the instructors' gender}

The male instructor was preferred compared to the female by most of the students (Table 7), $56 \%$ preference for male vs. $17 \%$ preference for female. A significant relationship was found between the students' preference and the gender of the instructor $(\mathrm{P}=0.001)$. Gender affects students' preferences where students prefer male traits over female traits for instructors (Bennett 1982; Burns-Glober and Veith, 1995).

Table 7. Students' preference of the instructors' gender

\begin{tabular}{|c|c|c|c|c|c|c|c|c|c|}
\hline \multirow{3}{*}{\multicolumn{2}{|c|}{$\begin{array}{l}\text { Preference of the } \\
\text { instructors' gender }\end{array}$}} & \multicolumn{6}{|c|}{ Gender of the instructor } & \multirow{4}{*}{$\begin{array}{c}\text { Chi-Square } \\
\text { Value }\end{array}$} & \multirow{2}{*}{ P-value } \\
\hline & & \multicolumn{2}{|c|}{ Female } & \multicolumn{2}{|c|}{ Male } & \multicolumn{2}{|c|}{ Total } & & \\
\hline & & $\mathrm{N}$ & $\%$ & $\mathrm{~N}$ & $\%$ & $\mathrm{~N}$ & $\%$ & & \multirow{4}{*}{$0.001 * *$} \\
\hline \multirow{3}{*}{$\begin{array}{l}\text { Which gender } \\
\text { would you } \\
\text { prefer as your } \\
\text { instructor? }\end{array}$} & Male & 103 & 47 & 143 & 64 & 246 & 56 & & \\
\hline & Female & 47 & 21 & 28 & 13 & 75 & 17 & \multirow[t]{2}{*}{14.59} & \\
\hline & $\begin{array}{l}\text { Don't } \\
\text { mind }\end{array}$ & 71 & 32 & 51 & 23 & 122 & 27 & & \\
\hline
\end{tabular}

Source: own compilation. $* *$ indicates significance level at 0.05

The students' gender didn't contribute to a significance difference in the preference of the instructors' gender. Both male and female students preferred male instructors than female instructors. In an experiment conducted on college students to evaluate their preference for the gender of the instructors, it was found that students showed preference for male candidates. In the experiment, students were given a hypothetical applicant's name - Sam, Sarah, and Dr. Lawson for a faculty teaching position and stronger gender bias were shown against the female applicant (Burns-Glover and Veith, 1995). Such apparent gender bias could be the result of men's dominance in a lecturing job which makes women seem out of place (Siskind and Kearns, 1997). Seeing such a difference in Ethiopian students' preference for the instructors' gender might not be a big surprise for a country where women academics are outnumbered by their men counterparts and has a minimal gender parity but not in such a significant difference.

\section{Conclusion}

This study aimed to shade insight about students' expectation and gender stereotype across the gender of the instructor and suggest ways to overcome the causes of the gender disparity. Consequently, the findings of this study revealed that when students were asked about their expectations related to the five dimensions of service quality, they showed no significant difference in their expectations towards female and male instructors. However, when they were asked about their general expectation on the performance of female and male instructors, the students' expectation of female instructors' performance was significantly lower than their counterparts. This implies that the students seem to be prejudiced against women. From the overlap of their expectations, it can be understood that the students' rational evaluations were taken over by emotional evaluation when they were asked general questions about their expectation of female and male instructors performance. Such kind of biased attitudes against women might be caused because women hold a lower position in Ethiopian society.The evidence provided in this study could alert higher education management to how extent that gender stereotypes exist against women instructors. It is also a wake-up call for governmental bodies, policymakers, and politicians to work on closing the gender gap in education and employment. All responsible bodies have to be involved to take a radical step for accepting women instructors and support them in their professional works. More women instructors should be encouraged in higher education jobs and universities are advised to have a gender- 
balanced workplace. Awareness should be raised on gender equality not only in higher education but in all service sectors. Unless gender equality is achieved, gender gaps could not be closed in service quality. The current Ethiopian political situation where more women are welcomed to leadership and management could be a good opportunity to achieve this goal. Bringing more women to higher positions and empowering them could eventually change the misconception on the performance of women. When women are given the opportunity to lead, they can prove to the society that they can do better. The society could finally put trust in women's ability to perform when they witness their accomplishments.

\section{Acknowledgment}

We are grateful to Kaposvár University, EFOP-3.6.1-16-2016-00007 project for supporting this study.

\section{References}

Africa check (2014). How many professors are there in South Africa? Retrieved November 25, 2019, from https://africacheck.org/reports/how-many-professors-are-there-in-sa/

All India Survey on Higher Education 2015-16.Retrieved November 25, 2019, from http://aishe.nic.in/aishe/reports

Anouka, E., Franz, W., Fetenu, B., Lenesil, A., \& Mahlet, M. (2015). Female faculty and leadership: Affirmative action and gender equality in 13 universities in Ethiopia. 1(1), 116.

Anselmi, D.L., \& Law, A.L (1998). Questions of gender, perspectives and paradoxes. Estados unidos de America: Editorial McGraw-Hill.

Arbuckle, J., \& Williams, B.D. (2003). Students' Perceptions of Expressiveness: Age and Gender Effects on Teacher Evaluations. Sex Roles: A Journal of Research, 49(9-10), 507516.doi:10.1023/A:1025832707002

Aronson, E., Wilson, T.D., Akert, R.M., \&Sommers, S.R. (2015). Social Psychology ( $9^{\text {th }}$ Edition). London: Pearson Education

Ashmore, R.D., Del Boca, F.K. (1979). Sex Stereotypes and Implicit Personality Theory: Toward a Cognitive-Social Psychological Conceptualization. Sex Roles 5 (2), 219-248. doi:10.1007/BF00287932

Australian Government, Department of Education and Training (2016). Selected Higher Education Statistics Staff Data. Retrieved November 25, 2019, from https:// docs. education.gov.au/node/42371

Bennett, S.K. (1982). Student perceptions of and expectations for male and female instructors: Evidence relating to the question of gender bias in teaching evaluation. Journal of Educational Psychology, 74(2), 170-179. doi:10.1037/0022-0663.74.2.170

Bem, S.L. (1981). Gender schema theory: A cognitive account of sex typing. Psychological Review, 88(4), 354-364. doi:10.1037/0033-295X.88.4.354

Boring, A. (2017). Gender biases in student evaluations of teaching. Journal of Public Economics, 145, 27-41.doi: 10.1016/j.jpubeco.2016.11.006

Burns-Glover, A. \& Veith, D. (1995). Revising Gender and Teaching Evaluations: Sex Still Makes a Difference. Journal of Social Behavior and Personality, 10(6), 69-80.

Burgess, D., \& Borgida, E. (1999). Who women are, who women should be: Descriptive and prescriptive gender stereotyping in sex discrimination. Psychology, Public Policy, and Law, 5(3), 665-692. doi:10.1037/1076-8971.5.3.665

Carson, L. (2001). Gender relations in higher education: Exploring Instructors' perceptions of student evaluations of teaching. Research Papers in Education, 16(4), 337-358. doi: $10.1080 / 02671520152731990$ 
Chamberlin, M.S., \& Hickey, J.S. (2001). Student evaluations of faculty performance: The role of gender expectations in differential evaluations. Educational Research Quarterly, 25(2), 3-14.

Cronin, J.J., \& Taylor, S.A. (1992). Measuring Service Quality: A Reexamination and Extension. Journal of Marketing, 56(3), 55-68. doi: 10.2307/1252296

Dalmia, S., Giedeman, D.C., Klein, H.A., \& Levenburg, N.M. (2005). Women in academia: An analysis of their expectations, performance and pay. Forum on Public Policy, 1(2), 160-177.

Directorate-General for Research and Innovation. (2015). She Figures. Retrieved November 25, 2019, from. doi: 10.2777/744106.

Eagly, A.H. (2003). The rise of female leaders. Zeitschrift für Sozialpsychologie, $\quad 34(3), 123-$ 132. doi: 10.1024//0044-3514.34.3.123

Firdaus, A. (2006). The development of HEdPERF: a new measuring instrument of service quality for the higher education sector. International Journal of Consumer Studies, 30(6), 569-581. doi: 10.1111/j.1470-6431.2005.00480.x

Gender Equality Bureau Cabinet Office. "Women and Men in Japan 2017". Retrieved November 26, 2019, from http://www.gender. go.jp/english contents/pr_act /pub/ pamphlet/women-and-men17/index.html

Global Gender gap report. Retrieved December 1, 2019 from http:// www3. weforum. Org /docs/WEF_GGGR_2018.pdf.

Goldberg, P. (1968). Are women prejudiced against women?. Trans-action, 5, 28-30. doi:10.1007/BF03180445

Hair J.F., Black W.C., Babin B.J., Anderson R.E., \&Tatham R.L. (2006). Multivariate data analysis 6th Edition. Pearson Prentice Hall: New Jersey.

Heilman, M.E. (2001). Description and prescription: How gender stereotypes prevent Women's ascent up the organizational ladder. Journal of social issues, 57(4), 657-674. doi:10.1111/0022-4537.00234

Johnson, V.E. (2003). Grade inflation: A crisis in college education. New York, NY: Springer.

Koenig, A.M. (2018). Comparing Prescriptive and Descriptive Gender Stereotypes about Children, Adults, and the Elderly. Frontiers in Psychology, 9 June. doi:10.3389/fpsyg.2018.01086

MacNell, L., Driscoll, A., \& Hunt, A.N. (2015). What's in a Name: Exposing Gender Bias in Student Ratings of Teaching. Innovative Higher Education, 40(4), 291-303. doi:10.1007/s10755-014-9313-4

Martilla, J. \& James, J. (1977). Importance-Performance analysis. The Journal of Marketing, 41(1), 77-79. doi:10.2307/1250495

Miller, J., \& Chamberlin, M. (2000). Women Are Teachers, Men Are Professors: A Study of Student Perceptions. Teaching Sociology, 28(4), 283-298. doi: 10.2307/1318580

Morris, L.V. (2011). Women in higher education: Access, success, and the future. Innovative Higher Education, 36, 145-147.doi:10.1007/s10755-011-9184-X

National Center for Education Statistics, IPEDS Data Center, "Full-Time Instructional Staff, by Faculty and Tenure Status, Academic Rank, Race/Ethnicity, and Gender (DegreeGranting Institutions): Retrieved November 25, 2019, from https://nces.ed.gov/ipeds/usethe-data

Noel, R.C. \&Allen, M.J. (1976). Sex and ethnic bias in the evaluation of student editorials. Journal of Psychology, 94, 53-58.

Oakes, P.J., Haslam, S.A. \& Turner, J.C. (1994). Stereotyping and Social Reality. Mass: Blackwell. 
Parasuraman, A., Zeithaml, V. A., \& Berry, L. L. (1988). SERVQUAL: A multiple-itemscale for measuring consumer perceptions of service quality. Journal of Retailing, 64(1), 12 40.

Risman, B.J. (2004). Gender as a social structure: Theory wrestling with activism. Gender \& Society, 18(4), 429-450.

Siskind, T.G., Kearns, S.P. Gender Bias in the Evaluation of Female Faculty at the Citadel: A Qualitative Analysis. Sex Roles 37, 495-525 (1997). doi: 10.1023/A:1025654802075

Sprague, J., \& Massoni, K. (2005). Student evaluations and gendered expectations: What we can't count can hurt us. Sex Roles: A journal of Research, 53(11-12), 779-793. doi: $10.1007 / \mathrm{s} 11199-005-8292-4$

Statistics Canada (2017). "Number and Salaries of Full-Time Teaching Staff at Canadian Universities," Retrieved November 25, 2019, from https://www150.statcan. gc.ca /n1 /daily-quotidien/170425/dq170425b-eng.htm

Teas, R.K. (1993). Expectations, performance evaluation and consumers perception of quality. Journal of Marketing, 57(4), 18-34. doi: 10.2307/1252216.

The world view (2018). Gender parities in Ethiopia realities and hopes. Retrieved November 27, 2019 from https://www.insidehighered.com/blogs/world-view/gender-parityethiopia-realities-and-hopes

The World Bank. Retrieved September 25, 2019, from https://datacatalog.worldbank.org/ dataset/gender-statistics

UN women. Retrieved February 20, 2020 from https://www.unwomen.org /mdgf/B/ Ethiopia_B.html. 


\section{Appendix}

\section{Part I}

5= Strongly agree $; 4=$ Agree $; 3=$ Neutral $; 2=$ Disagree $; 1=$ Strongly disagree

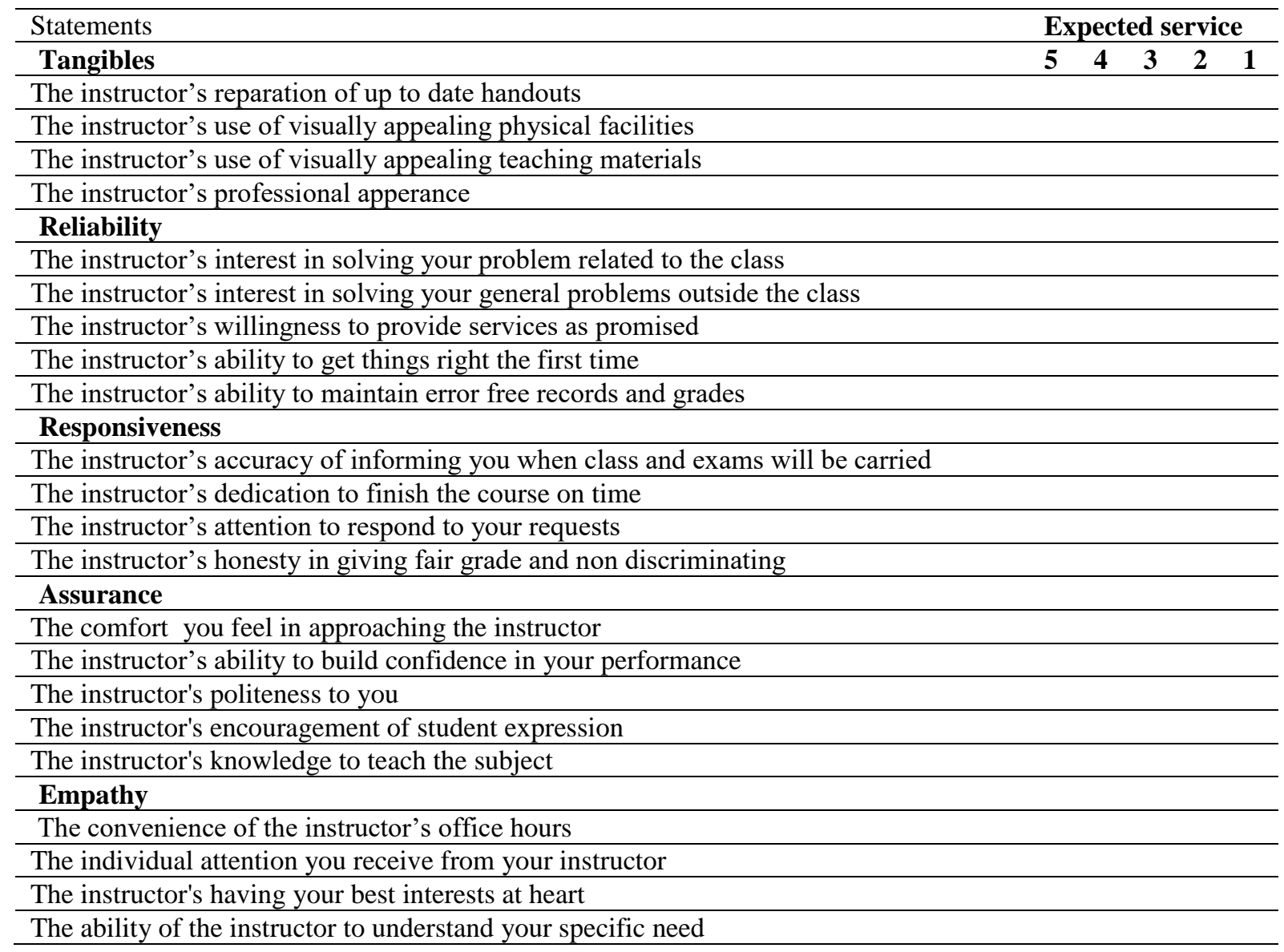

\section{Part II}

1. What is the gender of your instructor?
Female $\square$
Male

2. Which gender pops up in your mind first when you think of an instructor
Male
Female
None $\square$
Both $\square$

3. What kind of service do you expect from a female instructor?
Very good $\square$
Good
Average $\square$
Poor $\square \quad$ Very poor $\square$

4. What kind of service do you expect from a male instructor?
Very good $\square$
Good
Average $\square$
Poor

4. Which gender would you prefer as your instructor?
Male
Female
Don't mind 